Criminal history and social disadvantage as predictors of the severity of violent offending

\title{
Suonpää, Karoliina
}

2018

Suonpää , K , Kivivuori , J \& Aaltonen , M 2018 , ' Criminal history and social disadvantage as predictors of the severity of violent offending ' , International Journal of Comparative and Applied Criminal Justice , vol. 42 , no. 2-3 , pp. 139-155 . https://doi.org/10.1080/01924036.2016.1270843

http://hdl.handle.net/10138/324658

https://doi.org/10.1080/01924036.2016.1270843

unspecified

acceptedVersion

Downloaded from Helda, University of Helsinki institutional repository.

This is an electronic reprint of the original article.

This reprint may differ from the original in pagination and typographic detail.

Please cite the original version. 


\section{Criminal History and Social Disadvantage as Predictors of the Severity of Violent Offending}

\section{Authors and affiliations}

Karoliina Suonpää (the corresponding author). Institute of Criminology and Legal Policy, Department of Social Research, P.O. Box 24, FI-00014 University of Helsinki, Finland. karoliina.suonpaa@helsinki.fi. +358294120874.

Janne Kivivuori. Institute of Criminology and Legal Policy, Department of Social Research, P.O. Box 24, FI-00014 University of Helsinki, Finland. janne.kivivuori@ helsinki.fi. +358 29 4120862.

Mikko Aaltonen. Institute of Criminology and Legal Policy, Department of Social Research, P.O. Box 24, FI-00014 University of Helsinki, Finland. mikko.aaltonen@ helsinki.fi. +358 29 4120850 .

\section{Biographies}

Karoliina Suonpää, M.Soc.Sc., is a doctoral candidate at the Institute of Criminology and Legal Policy, University of Helsinki. She is currently writing her sociology dissertation on lethal violence focusing on the aspects of cumulative social marginalization, situational factors of lethal events and life-course trajectories of offenders.

Janne Kivivuori is professor of Criminology at the Institute of Criminology and Legal Policy, University of Helsinki. His research has focused on homicide, delinquency and criminological research methods. He has published in key journals of the field, such as Homicide Studies, European Journal of Criminology, and Crime and Justice - A Review of Research.

Mikko Aaltonen, D.Soc.Sc, is a senior researcher at the Institute of Criminology and Legal Policy, University of Helsinki. His current research focuses on the deterrent effect of higher fines and the dynamic association between offending and victimization. 


\section{Criminal History and Social Disadvantage as Predictors of the Severity of Violent Offending}

Lethal violence is often seen as the tip of the iceberg and homicide perpetrators are seen as manifesting the most extreme number of various risk factors. This article explores whether that is the case. Using a unique dataset combining data from several administrative registers with a nationally representative sample of different types of police-reported violence committed during 2010-2011 (N=26,303 offenders) in Finland, we compare the offenders of five different types of violence (minor assault, assault, aggravated assault, attempted homicide, and completed homicide). In addition, we examine the association between the severity of violence and prior criminal history and different types of strain. The results give partial support to the hypothesis: the more serious the violence, the more crime-prone and socially disadvantaged the offender. Yet, lethal offenders do not stand out alone; the division, rather, appears to be between offenders of serious (aggravated assault, attempted homicide, completed homicide) and less serious (minor assault, assault) forms of violence.

Keywords: homicide, violence, criminal history, intergenerational transmission, socioeconomic status, register-based 


\section{Introduction}

Violent crimes tend to have more long-lasting and serious consequences than other forms of crime. They cause both immediate and lasting mental and physical health problems to victims (Weijer, Bijleveld, \& Blokland, 2014) and increase fear and avoidant behaviours of the public (DeLisi et al., 2010). Lethal violence is the most severe form of violence with drastic consequences to the victims and their families. In the monetization studies estimating the cost of various crimes, homicide was ranked as the most costly offence (Wickramasekera, Wright, Elsey, Murray, \& Tubeuf, 2015; DeLisi et al., 2010). In addition, homicide has large intangible costs: besides the lives that are lost, more than half of the family members of the homicide victims suffer from mental health disorders years after the lethal event (Poijula, 2010).

The severity of interpersonal violent offending varies from minor assaults to more serious crimes such as aggravated assaults and lethal violence. Lethal offenders are often seen as manifesting the most extreme number of various risk factors (e.g., Hardwick \& RowtonLee, 1996; Piquero, MacDonald, Dobrin, Daigle, \& Cullen, 2005). Yet, prior studies explicitly comparing the criminal history and other social determinants of lethally and nonlethally violent criminals are rare and the results have been somewhat ambiguous. For instance, Smit, Bijleveld, Brouwers, Loeber, and Nieuwbeerta (2003) and Ganpat, Liem, Van der Leun, and Nieuwbeerta (2014) contrasted the criminal histories of groups of offenders of severe violence. In the study by Smit et al. (2003), the differences in the criminal careers of offenders of completed and attempted homicide did not reach statistical significance. Ganpat et al. (2014) found that, surprisingly, the non-lethally violent offenders had more severe criminal histories than lethally violent perpetrators. In two other studies contrasting lethal versus non-lethal violence, only domestic violence committed by men (Dobash, Dobash, Cavanagh, \& Medina-Ariza, 2007) or violence committed by young men (DiCataldo \& Everett, 2008) have been included, and research designs may have suffered from small sample 
sizes. Also, risk factors other than criminal history have been studied less rigorously, and offenders committing less serious violence have not been included in such studies.

In this study, we add to prior research by using a very large dataset for examining if the severity of violence is associated with individual criminal propensity (measured by criminal history), parental criminal propensity (measured by offenders' parents' unconditional prison sentences), and social disadvantage (measured by low annual income, lack of secondary education, and immigrant background). We combine different administrative datasets resulting in a nationally representative sample of police-reported violence committed in Finland in 2010-2011 ( $\mathrm{N}=26,303$ offenders) and compare the offenders of five different types of violence (minor assault, assault, aggravated assault, attempted homicide, and completed homicide). To our knowledge, this is the first empirical study to include the offenders of less severe forms of violent crime and such a wide set of social determinants in a study examining the severity of violence. Associations between variables are estimated by using logistic and linear regressions.

\section{Research context}

In Finland, almost 34,000 assault offences and 299 attempted homicides were reported to the police in 2015 (Kääriäinen et al., 2016). Same year, 104 individuals died as victims of lethal violence (Lehti, Suonpää, \& Kivivuori, 2016). Compared to other Western and Nordic countries, Finland has an exceptionally high rate of homicide (WHO, 2013). The Nordic welfare states have similar social policies and share many characteristics (Esping-Andersen, 1999), and thus it is not surprising that this difference between Finland and other Scandinavian countries, the 'Scandinavian divide', has been one of the central riddles of Nordic homicide research (Kivivuori \& Lehti, 2011; Lehti \& Kivivuori, 2005). However, according to multinational victim surveys (van Dijk, Kesteren, \& Smit, 2007) and school surveys considering delinquent behaviour of adolescents (Kivivuori, 2007), Finland does not appear either as a particularly 
criminal or violent country. Overall, multinational studies comparing aggregate-level crime rates of different countries and cities have shown that lethal violence correlates poorly with crime in general (Zimring \& Hawkins, 1999).

The characteristics differentiating Finnish homicides from comparable nations associated with lower levels of lethal violence include the relatively high age of offenders, homicides taking place in the regional peripheries, high share of alcohol-related violence, and an exceptionally strong component of social disadvantage regarding both the offenders and victims (Savolainen, Lehti, \& Kivivuori, 2008). A study comparing lethal violence in Finland, Sweden, and the Netherlands showed that homicides were most instrumental in the Netherlands and most expressive in Finland: in the Netherlands, lethal violence had a closer link with general criminality and organized crime, but in the Nordic countries, and in Finland in particular, homicides more often resulted from trivial altercations and quarrels in alcohol-related situations (Liem et al., 2013). Similarly, the difference between Finnish and Swedish homicide rates is largely explained by violence among economically inactive and alcoholised middle-aged males (Kivivuori \& Lehti, 2006; Kivivuori \& Lehti, 2011). In all Nordic countries, this sociodemographic group is responsible for most of the homicides, but the rates are particularly high in Finland. Building on their earlier variant of institutional anomie interpretation (Kivivuori \& Lehti, 2006), the authors suggested that some features of the Finnish welfare policies inadvertently enable a lifestyle favourable to alcohol-related lethal violence in specific demographic groups (Kivivuori \& Lehti, 2011).

Prior research raises the question, whether or not lethal violence is best understood as a distinct phenomenon, or if homicide should be seen as an extreme manifestation of various violent behaviours, explained by similar theories for other kinds of violent offending. This question parallels the debate concerning intimate partner violence, where the "gender perspective" implies that intimate partner violence between genders have different aetiologies 
than other types of violence, whereas the "violence perspective" suggests that they have similar aetiologies (Felson \& Lane, 2010). In the Finnish study comparing different types of lethal violence, social disadvantage was associated with all homicide types, regardless of the victim's gender (Kivivuori \& Lehti, 2012). Similarly, it is important to examine if the most severe and rare forms of violent crime share particular characteristics separating them from more common and less serious types of violence, and if they can be predicted based on specific risk factors of the offender.

Prior research has shown that a majority of lethal perpetrators have a criminal history (Dobash, Dobash, Cavanagh, \& Medina-Ariza, 2007; Farrington, Loeber, \& Berg, 2012; Soothill, Francis, Ackerley, \& Fligelstone, 2002). Also, lethal offenders with a criminal history are likely to have a history of violent crime (Dobash et al., 2007; Farrington et al., 2012; Ganpat et al., 2014). In the literature, this association of past and future criminality has often been understood as an individual criminal propensity which is grounded in the idea that people differ in their time-invariant tendency to commit crimes (e.g., Gottfredson \& Hirschi, 1990). According to Moffitt's (1993) influential taxonomy, a large group of people participates in criminal offending temporarily during their adolescence, but only a small group of individuals engages in antisocial behaviour at every stage of life. For this group, antisocial behaviour is life-course-persistent, caused by the interaction of neuropsychological problems and criminogenic environments, and their crimes tend to be more often serious, and more often violent offences (Moffitt, 2006).

Most of the empirical studies on social determinants of violence indicate that violent offending is concentrated in the lower social strata (Farrington, 2007). The inverse association of socio-economic status and violence applies to victims as well, and this is found in victim surveys as well as in official registers (Aaltonen, Kivivuori, Martikainen, \& Sirén, 2012; Nilsson \& Estrada, 2006). Considering the lethal violence in particular, homicide offenders tend 
to be from the lower social strata (Kivivuori \& Lehti, 2006; Kivivuori \& Lehti, 2012). Merton’s (1938, 1968) anomie theory of crime has been a particularly influential formulation of the strain-theoretical approach. According to this point of view, criminal offending results from a contradiction between culturally shared values and goals - such as affluence and wealth - and the structurally given means of people from the lowest social strata to pursue these goals. Deprivation of resources causes frustration, which can result in diffuse hostility and violent aggression (Hsieh \& Pugh, 1993; Messner, 1983).

However, advocates of propensity-based theories would argue that the link between low socio-economic status and crime is spurious: maladaptive behaviour during childhood may lead to downward social mobility (Caspi, Elder, \& Bem, 1987), and individual tendencies towards criminal behaviour can cause both the low socio-economic status and criminal behaviour, among other negative outcomes (Gottfredson \& Hirschi, 1990; Moffitt et al., 2011). According to Sampson and Laub's (1997) dynamic view, the stability of delinquency over the life-course should be understood, instead, as a process of cumulative disadvantage: crime itself causally alters the future probability of criminal behaviour. Cumulative disadvantage is therefore not only a result of stable individual traits but a continuing process, where childhood and adolescent delinquent behaviour fosters later crimes by weakening social and institutional bonds linking adults to society.

Homicide, in particular, is often seen as an extreme manifestation of various risk factors (e.g., Hardwick \& Rowton-Lee, 1996; Piquero et al., 2005). The strain-theoretical tradition would seem to imply that the frequency and gravity of violence would increase with advanced levels of disadvantage. Similarly, one could hypothesize that most serious violent offenders have come further down a path of cumulative disadvantage. Consistent with such expectations, a Finnish study by Aaltonen (2013) found that social disadvantage increased violent and property crimes committed in a dose-response fashion: the lower the socio-economic status, the 
higher the risk of crime among young adults. Both victims and offenders of violence became on average more marginalized when the seriousness of assaults increased. However, that study did not address lethal violence. A similar pattern is seen when offenders sentenced to different sanctions are compared, as the offenders sentenced to prison terms in Finland differ from those serving lesser punishments: those sentenced to unconditional prison terms had more often only basic education, debt problems and belonged to the lowest income quintile than offenders sentenced to community service, and community service convicts differed similarly regarding conditional sentence convicts (Aaltonen, 2016). Building on this, it seems plausible to expect a similar progression on the continuum of seriousness of the violence: the greater the dosage of individual criminal propensity and social disadvantage, the greater the probability of lethal violence.

\section{Prior research comparing lethal and non-lethal violence}

Historically, homicide research has formed a distinct field separate from studies examining violent behaviour in general, originally because homicide figures were seen as least compromised by the problem of hidden crime (Kivivuori, 2017, forthcoming). Prior research explicitly comparing the criminal histories and social determinants of lethally and nonlethally violent offenders seems scarce and has yielded somewhat mixed results. Studies differ in, for instance, their inclusion of different violence types, the measurement of strain and social disadvantage, and the generalizability of results. Also, the data sources differ and reflect different legal systems and offenders committing less serious violence have not been included in such studies. In this section, we describe studies contrasting lethal and non-lethal violence in a more detailed manner.

Theories of criminal propensity and strain are general theories in nature: they explain various kinds of criminal acts, including lethal violence. In most empirical tests of these 
theories, causal links are difficult to establish, but it is an empirically supported notion that criminal propensity and strain are associated with increased criminal offending. However, theories of criminal propensity (e.g., Gottfredson \& Hirschi, 1990) or strain (Merton, 1938, 1968), or cumulative disadvantage (Sampson \& Laub, 1997) are less explicit regarding how their preferred predictors relate to the severity or lethality of the criminal behaviour. They do not explicitly argue, for instance, that the greater the dosage of criminal propensity, or social disadvantage, the greater the probability of lethal versus non-lethal violence. Moffitt (1993, 2006), on the other hand, comments on the severity of crime since, in her taxonomy, there are two qualitatively distinct groups with different aetiologies. Moffitt (1993) suggested that genetics play greater role in explaining the criminality of life-course-persistent offenders, and this was supported by the findings of Barnes, Beaver, and Boutwell (2011), yet in some studies the differences have not been found (meta-analysis by Rhee \& Waldman, 2002; review by Slutske, 2001). Prior studies have indicated the concentration of criminal offending in families (Bijleveld \& Wijkman, 2009; Farrington, Jolliffe, Loeber, Stouthamer-Loeber, \& Kalb, 2001; Weijer et al., 2014) and the impact of gene-environment interaction between heritable tendencies and childhood maltreatment (Byrd \& Manuck, 2013). Studies concerning criminal trajectories of perpetrators have shown that although most adolescent offenders desist from offending, the crimes committed by those who continue to offend into adulthood tend to escalate in severity over time (Blumstein et al., 1988; Le Blanc \& Loeber, 1998). In addition, in a Finnish study considering cumulative disadvantage, the victims of violence became more socially disadvantaged, on average, when the seriousness of violence increased (Aaltonen, 2013).

In their review of literature, Piquero, Jennings, and Barnes (2012) stated that violent offenders tend to be frequent offenders who do not specialize in violence but participate in various forms of criminal offending during their criminal career: only a small proportion of 
crimes committed during most individual criminal careers are violent, at least when criminal activity is measured with official records. Yet, in a study comparing young violent and nonviolent offenders, being a chronic violent offender did not necessarily imply the involvement in frequent non-violent offending (McCuish, Corrado, Hart, \& DeLisi, 2015). In a study examining the arrest histories of lethal gang and non-gang offenders, small evidence of specialization was found but, in general, homicide offenders were found to be versatile in their offending leading up to the homicide (Adams \& Pizarro, 2014). The most severe violent offenders were found to have substance abuse issues (DeLisi, Vaughn, Salas-Wright, \& Jennings, 2015), in Finland, alcohol abuse in particular (Kivivuori \& Lehti, 2006; Kivivuori \& Lehti, 2011).

A handful of studies have examined the association of criminal history and/or social disadvantage and the severity of crime. Ganpat et al. (2014) compared the criminal records of lethally $(\mathrm{N}=3,678)$ and non-lethally $(=4,788)$ violent offenders in the Netherlands. The former group consisted of criminals, whose index crime was manslaughter or murder, while the latter group of perpetrators were convicted for attempted manslaughter or attempted murder. Results suggested that although the majority of both groups had a criminal history, non-lethally violent perpetrators had a more severe criminal history than lethally violent offenders. An individual's history of prior violent crimes seemed to decrease the probability of lethal violence compared to non-lethal violence. However, the results were partially ambiguous: the groups did not differ in terms of having a criminal record. Furthermore, the total number of crimes appeared to increase the risk of lethal outcome. Considering the age and the ethnicity of the offenders, young age and immigrant background increased the probability of lethal versus non-lethal violence.

DiCataldo and Everett (2008) contrasted two groups of young males who had committed lethal $(\mathrm{N}=33)$ or non-lethal violence $(\mathrm{N}=38)$ and were confined in the same secure detention 
programme in the USA. Non-lethally violent males had significantly greater numbers of total offenses, and also more violent offenses. Considering the family history during childhood, there were no statistically significant differences in parental criminality or parental death, separation, or divorce but non-lethally violent offenders reported significantly more frequent sibling delinquency and out-of-home placements. Overall the results suggested that non-lethal perpetrators seemed to be more problematic, based on many of the variables of analysis. However, the authors warned that some of the differences identified in the study may have been caused by sampling bias: the number of subjects was small and all of them were confined within the same secure detention programme.

Dobash et al. (2007) compared lethal and non-lethal violence against an intimate female partner in England, Wales, and Scotland. The group of lethally violent offenders consisted of men $(\mathrm{N}=106)$ who were convicted for the murder of a current or former partner in a marital, cohabiting, or serious dating or engaged relationship. The group of non-lethally violent perpetrators consisted of men $(\mathrm{N}=122)$ convicted of an offense relating to domestic violence. In regard to criminal history, the authors found that lethally violent offenders were less likely to have had at least one previous conviction or previous violent conviction. Results were similar, considering other risk factors as well: lethally violent criminals were more conventional with respect to their childhood backgrounds, education, and employment.

Smit et al. (2003) used the Dutch Homicide Database for examining the differences between offenders who had been convicted for homicide $(\mathrm{N}=142)$, attempted homicide $(\mathrm{N}=1,054)$, aggravated assault $(\mathrm{N}=604)$ and attempted aggravated assault $(\mathrm{N}=1,437)$. Perpetrators of attempted and completed homicide had more previous criminal offenses in total, but surprisingly fewer violent offences than perpetrators of attempted and completed aggravated assault. When contrasting only the offenders of completed and attempted homicide, the differences in their criminal careers did not reach statistical significance. 
To sum up, there seems to be an element of non-linearity in the correlates of serious violence, so that homicide in many analyses appears less connected to social disadvantage and criminal history than do other forms of violence. However, existing research on lethal/nonlethal violence divide is largely based on data from the US, the UK and the Netherlands. The patterns of lethal violence in these countries differ in many respects from the situation in the Nordic area. This holds true also in regard to the Netherlands (Granath et al., 2011).

\section{Current study}

\section{Research questions and data}

Based on the aforementioned theoretical literature and earlier empirical findings, we have formulated the following hypothesis: The more serious the violence, the more crime-prone and socially disadvantaged the offender. Individual criminal propensity is measured by an offender's criminal history of prior violent crimes, drug-related crimes, property crimes, and incarceration. Finland, among other Nordic countries, has some of the lowest incarceration rates in the world (Lappi-Seppälä, 2011), and incarceration can be understood as reflecting involvement in severe crime. Parental criminal propensity is measured by prison sentences of an offender's parents.

Social and economic strain is measured by annual income, lack of secondary education, and immigrant background. In the Nordic countries, immigrants are overrepresented in the crime statistics (e.g., Martens \& Holmberg, 2005; Skardhamar, Aaltonen, \& Lehti, 2014), and it is suggested that they experience socio-economic disadvantage and problems with social integration (Skardhamar, Aaltonen, \& Lehti, 2014). Put in the context of strain theory, immigrant status may be understood as a risk factor increasing an individual's likelihood to experience social strain and disadvantage. The associations of the severity of violent crime and individual criminal propensity and strain are estimated with logistic and linear regressions. 
Our primary data comes from Risk Factors of Crime in Finland (RFCF) which was initiated in 2008 by the Institute of Criminology and Legal Policy (ICLP) to enable registerbased research on determinants of crime in Finland. Originally, RFCF is a random sample of 150,010 Finnish residents drawn from the population register and it combines information from different administrative registers. In addition to this large sample of the normal population, the dataset comprises a $50 \%$ random sample of selected police-reported violent crimes during 2010-2011. In this study, we used this sample of violent crimes supplemented with a total population sample of suspects of crimes investigated as homicides during 2010-2011. The suspect was used as the sampling unit. Non-lethal violent crimes included were minor assault, assault and attempted assault, aggravated assault and attempted aggravated assault, and attempted homicide. Homicide included penal code titles murder, manslaughter, killing, and infanticide. Negligent homicide and grossly negligent homicide were included when in conjunction with the penal code titles on assault. Hence, the data included all persons suspected by the police of the crimes included in the sample, even if the criminal investigation did not lead to a conviction. It is common that some of the cases investigated as more serious offenses will change their rubric to less serious ones when the case goes to court (for instance, an incident investigated as an aggravated assault can get a conviction as an assault). Also, some of the suspects can be exonerated. For simplicity, suspects are referred to as offenders in this study.

Offenders under 15 years old were omitted from the data since they are not criminally liable, and hence cannot have a criminal record of prior convictions. As a consequence of this, our research focuses on adult offenders. A small number of offenders commits the majority of crimes: the same individuals could be suspected of various crimes during the same time frame. In this study, the same offender could only be counted once in each of the five offense types. Hence, in this analysis, the index crime is the first crime of the offender in a specific type of crime, and other similar offenses committed by the same person were deleted from the dataset. 
Cases without clear personal identification number were omitted.

Our final dataset consisted of 7,970 offenders of minor assault, 15,817 offenders of assault or the attempt, 1,995 offenders of aggravated assault or attempt, 318 offenders of attempted homicide, and 203 offenders of completed homicide. Here, assaults and aggravated assaults include attempts, while minor assaults do not since the attempt of minor assault is not a punishable act. In contrast, attempted and completed homicide offenders were separated into two groups. The Finnish personal identification number was used for combining information from other data sources. Basic demographic data such as age, gender, and country of origin was obtained from the Population Information System maintained by the Population Register Centre. Information about taxable income during five years before the index crime was gathered from the Finnish Tax Administration, and information about the highest accomplished education at the end of the year 2010 was obtained from Statistics Finland.

The data on prior crimes and parental criminality was gathered from two registers maintained by the Institute of Criminology and Legal Policy. Originally the data on convictions and fines was gathered by the Legal Register Centre, and the data on police-reported violent crime comes from the Police. The data on prior convictions of the offenders was gathered from the last five years before the index crime. The data on parental incarceration was available from the year 1992 onwards. When the variable considering a mothers' prior incarceration was constructed, offenders whose mothers were not identified were coded as missing $(\mathrm{N}=2,445)$. Then the dummy variable describing whether a mother had been in prison was created for those offenders whose mothers' identities were known. The same was done with the information considering fathers: the variable was coded as missing for the offenders whose fathers were not identified $(\mathrm{N}=3,797)$. Finally, the variable considering parental incarceration was coded as a dummy describing whether any of the parents, whose identity was known, had received a prison sentence. 
Immigrant background was coded, based on the offender's country of birth. In the model VIII estimating the association of different types of violent crime and immigrant status, immigrant background was used as a dummy variable reflecting whether or not the offender was born in Finland. In other models, immigrant status was used as a control variable, and a more detailed classification was used: countries were divided into eight macro-geographical regions (Finland, Eastern Europe, other Europe, North America, Middle and South America, Asia, Africa, and Oceania) and "unknown". In the models I-VII, this variable with nine categories was used as a control.

\section{Analytic strategy}

In the following analyses, logistic and linear regression are deployed. As the intention of the model is to find out whether the offenders committing violence of different severity differ, the index crime (minor assault, assault, aggravated assault, attempted homicide, or homicide) is technically the independent variable in the models, whereas the measures of prior crime and social disadvantage are used as dependent variables. Obviously, this does not mean that index crime causally affects prior crime or prior social disadvantage. Rather, we are testing, if the severity of violent offending is associated with criminal history and disadvantage. Because the existence of criminal record, parental incarceration, immigrant background or the lack of secondary education are dichotomous variables, we used logistic regression which is a suitable model for binary outcomes. Reference group is the group of offenders whose index crime was an assault $(\mathrm{N}=15,817)$. In the following analyses, results are controlled for the population structure (age and gender), to control for the differences in age and sex composition of groups committing violence in different degrees of severity. We additionally estimated Poisson regression models with the numbers of crimes as a dependent variable and type of index crime as an independent variable, and results were practically similar. Our main goal is to study 
whether or not five different groups of offenders have statistically significant differences in regards to prior crime and social disadvantage.

\section{Results}

\section{Descriptive results}

Table 1 displays the descriptive results regarding the differences of five types of offenders: offenders of minor assault, assault, aggravated assault, attempted homicide and completed homicide. In terms of demographic variables, the share of males is greatest in the group of homicide offenders $(88.7 \%)$. Homicide offenders are also a few years older than offenders of other forms of violence. The table also shows the percentage of offenders born outside Finland, indicating that immigrant background was more prevalent for assault than for homicide.

[Table 1 near here].

Regarding measures of individual criminal propensity, slightly over one tenth $(11.5 \%)$ of offenders of minor assault had a criminal record of violent crime, compared to more than one third of offenders of attempted homicide $(31.4 \%)$ and homicide (35.0\%). Similarly, with criminal history measured in terms of drug-related crimes, property crimes, or prison sentence, offenders whose index crime was a minor assault or an assault, had committed distinctly fewer prior crimes than offenders of aggravated assault, attempted homicide and completed homicide. Considering parental criminal propensity, offenders of serious violence were more likely to have parents who had served a prison sentence: parental incarceration rate was seven percent (6.6\%) for offenders of minor assault and 13 percent $(13.1 \%)$ for offenders of completed homicide. 
Mean annual income during the five years prior to the index offense was highest for the perpetrators of minor assault and assault. Offenders of homicide attempt had the lowest average income $(6,654 \mathrm{e})$. However, distribution of income is highly skewed (skewness=3.44; $\mathrm{SE}=0.02$; kurtosis 38.22; $\mathrm{SE}=0.03$ ) and the results should be interpreted with caution. Many of the offenders did not have any taxable income during the last five years before the index crime. Most of the offenders did not have any secondary education. Yet, the five offender groups differed in this respect: offenders, who committed a homicide attempt or aggravated assault, had the lowest education on average $(68.2 \%$ and $66.5 \%$, respectively).

\section{Criminal propensity and the severity of violent crime}

Figure 1 displays the results for the association of different offender types and prior criminal history during the five years before the index crime. Offenders of assault $(\mathrm{N}=15,817)$ are the reference group and get the value of 1 . Gender, age, and immigrant status are controlled for in all models. The dependent variable is a dichotomous variable, existence of a prior violent record, drug-related crime record, property crime record, or prison sentence, and the independent variable is the index crime.

In all of the models considering criminal propensity, the group committing minor assault has the smallest odds of having a prior crime record, the group committing assault the second smallest. The order of the last three groups varies. In the first model, results describing the association of the severity of the index crime and history of violent crimes are shown. Offenders of the completed homicide have the greatest odds $(\mathrm{OR}=3.53)$ of having a criminal history record. In the models II-IV, lethal offenders do not stand out as the most extreme group but the offenders of attempted homicide have the greatest odds of having committed drug-related crime $(\mathrm{OR}=3.84)$, property crime $(\mathrm{OR}=2.87)$, and having received an unconditional criminal sentence 
$(\mathrm{OR}=4.27)$. Yet, the confidence intervals of the three most violent groups are partly overlapping.

[Figure 1 near here].

Figure 2 displays the results concerning parental criminal propensity. Offenders of minor assault and assault differ from the other three groups by having statistically significantly smaller odds of parental incarceration. Compared with the reference group, homicide offenders, for instance, have two times greater odds of having at least one parent in prison $(\mathrm{OR}=2.03)$. However, the confidence intervals of the groups of the severe violence are again partly overlapping.

[Figure 2 near here].

\section{Strain and social disadvantage and the severity of violent crime}

Figure 3 shows the results of a linear regression estimating the association of the severity of violence and annual income during the five years before the index crime. Mean annual income of the reference group (assault offenders) is $11,244 €$. When the control variables are included in the model, homicide offenders earn annually on average $6,279 €$ less than the reference group, and minor assault offenders earn on average $905 €$ more than the reference group. However, the confidence intervals of the attempted and completed homicide offenders are largely overlapping.

[Figure 3 near here]. 
Figure 4 displays the associations of different types of violent crime and two measures of strain and social disadvantage: lack of secondary education and immigrant status. Age and gender are controlled for in both of the models, immigrant status is controlled for only in model VII. Similarly as for other models, offenders of minor assault $(\mathrm{OR}=0.91)$ and assault differ from the other three groups. They have the smallest odds of lacking a secondary education, offenders of attempted homicide have the greatest $(\mathrm{OR}=2.06)$. Again, the confidence intervals of the last three groups are partly overlapping and lethal offenders do not stand out as a distinct group. Considering the immigrant background (model VIII), the results are different. Offenders of minor assault $(\mathrm{OR}=0.99)$ and assault have the greatest odds of being immigrants, the offenders of severe violence the smallest. Based on this model, immigration status does not increase the risk of committing lethal versus non-lethal violence.

[Figure 4 near here].

\section{Discussion}

\section{Main findings}

Lethal violence is often seen as an extreme manifestation of various risk factors (e.g., Hardwick \& Rowton-Lee, 1996; Piquero et al., 2005). As stated before, classical theories of individual criminal propensity (e.g., Gottfredson \& Hirschi, 1990), strain (Merton, 1938, 1968), or cumulative disadvantage (Sampson \& Laub, 1997) were not explicit regarding the severity or lethality of the criminal offending. Moffitt's $(1993,2006)$ taxonomy commented on the severity of the criminal career in a more explicit way, but not on the question of lethality in particular. In our study, we tested if individual criminal propensity (measured with criminal history), parental criminal propensity and three different measures of strain and social disadvantage predict the severity of the violence, and if the lethal offenders are the most extreme group in 
regard to the above-mentioned risk factors. We added to prior research comparing lethal and non-lethal violence by using a very large dataset, including offenders of less serious violence, and exploring also the association between parental incarceration and offence seriousness. Based on the aforementioned theories on criminal propensity and strain, we expected to find that the more serious the violent offence, the more crime-prone and socially disadvantaged the offender. Especially, we expected that lethal offenders would form a distinct group at the peak of the disadvantage continuum, the highest levels of social and economic strain, prior crime and parental incarceration.

As stated in prior research (e.g., Piquero et al., 2012, Adams \& Pizarro, 2014), violent offenders were generally versatile in their offending. Considering the association of prior crime and severity of violence, the results partially supported the hypothesis: the more serious the violence, the more crime-prone and disadvantaged the offender. Yet, lethal offenders did not stand out as the most problematic group. Instead, the division appeared to be between offenders of serious violence (aggravated assault, attempted homicide, and completed homicide) and less serious violence (minor assault, assault). A similar pattern was found when criminal propensity was measured with the existence of a prior record of violent crimes, drug-related crimes, property crimes, or prior incarceration. Concerning the parental criminal propensity, results were virtually the same. The mechanism behind the association of parental incarceration and violent offending was not examined here, but it is believed that both the genetics and social environment during childhood have an impact on criminal behaviour (Byrd \& Manuck, 2013; Moffitt, 1993, 2006; Weijer et al., 2014).

Strain and social disadvantage was measured via annual income, lack of education, and immigrant status. In regards to annual income, offenders of minor assault and assault earned distinctly more income than offenders of aggravated assault, who also differed from the offenders of attempted and completed homicide who together formed the most socially 
disadvantaged group. However, the distribution of income is highly skewed since many of the offenders did not have any taxable income during the follow-up period and the results should be interpreted with caution. The results concerning the lack of secondary education resembled the measures of prior crime: the groups of aggravated assault, attempted homicide, and completed homicide had the greatest odds of lacking a secondary education. Based on this measure, the offenders of attempted homicide seemed to be the most marginalized group, but the confidence intervals were greatly overlapping. The variance in the education of homicide offenders was wide. In our study, immigrant background was not associated with the probability of lethal versus non-lethal violence, even when the age and gender were controlled for.

In the current analyses, attempted and completed homicide offenders did not differ statistically significantly. This finding differs from prior research by Ganpat et al. (2014), DiCataldo and Everett (2008) and Dobash and Dobash (2007), but is consistent with the findings of Smit et al. (2003). However, the direction of the differences in criminal histories of these two groups was the same as in all of these studies. Attempted homicide offenders were more crime prone than homicide offenders in three of our four measures of criminal history (history of drug-related crime, property crime and incarceration history). Only in the case of violent crime history did homicide offenders stand out as the most criminal group.

In sum, our study corroborates the earlier empirical findings from international literature: homicide offenders do not stand out as the most extreme group in regard to their criminal propensity and social disadvantage. As observed in the studies of Ganpat et al. (2014), Dobash et al. (2007), and DiCataldo and Everett (2008), there seemed to be an element of non-linearity in the correlates of serious violence, meaning that homicide in some analyses appears to be less connected to criminal history and social disadvantage than other forms of violence.

\section{Data strengths and limitations}


Drawing on the unique register data resources available in the Nordic countries (Lyngstad \& Skardhamar, 2011), we used a large, nationally representative dataset based on a random sample of police-reported violent crimes during 2010-2011. In addition to this, we used a total sample of completed homicides committed during the same two years. Use of the Finnish personal identification number enabled us to combine information from other data results, such as country of birth, education, annual income, prior crime record, and the incarcerations of the offenders and their parents. The advantages of using register-based data include a retrospective creation of longitudinal data, and having few or no nonresponses or attrition (Lyngstad \& Skardhamar, 2011). Our results can be generalized to violent offenders in Finland and apply to multiple cohorts.

As in all register based research, our analyses are limited to factors that are included in the available registers. Data on prior crime and annual income was gathered from five years before the index crime. We did not have the information on the age of onset of the criminal career, and were therefore not able to study whether or not the young age at the time of the first criminal offence is correlated with more severe offending in later life, as Moffitt (1993) suggested. Offenders younger than 15 were omitted from the data. In Finland, the criminal liability starts at the age of fifteen, meaning that crimes committed before that age are unobservable in conviction data. Hence, they could not have prior convictions, and considering our measures of socio-economic status, they do not usually have secondary education or annual income either. Another limitation is related to data considering the information of an offenders' parents' prior incarceration: this data was not available for every subject of the study due to missing parental data, it was available only from the year 1992 onwards and we did not have the information about the exact timing of the prison sentences. According to Weijer et al. (2014), the impact of parental incarceration depends on the age of the offender since both the genetics and social learning play a role in multigenerational continuity of offending. In later 
studies, this should be examined. However, these limitations do not explain the differences between the five groups: parental incarceration was associated with the severity of violent crime. Nevertheless, future studies would benefit from more precise data of the criminal trajectories of both the offenders and their parents.

Our dataset consists of individuals who are suspects of crime, and thus reflect police control activities, even if the criminal investigation did not lead to a conviction. While labelling theorists justly warn that police control can be biased against the disadvantaged populations, Finnish analyses indicate that police attention is mainly driven by the criminality of the suspects (Saarikkomäki \& Kivivuori, 2013), a finding that supports the use of register sources. Taken together, we argue that the benefits of register-based studies surpass the alternatives.

\section{Conclusions}

Lethal violence is the most serious of all crimes and have the most serious consequences to the victims and their families. Our findings indicate that individual criminal propensity, parental criminal propensity, and social disadvantage are associated with lethal offending within a population of violent offenders: homicide offenders were more likely to have a criminal history and parental incarceration, and had experienced more strain and social disadvantage, as measured with low annual income and the lack of a secondary education, than offenders of assault and minor assault. However, lethal offenders did not differ statistically significantly from offenders of aggravated assault and attempted homicide. In the Netherlands, offenders of attempted homicide had a more extensive criminal history than offenders of completed homicide, and authors have suggested that individuals who were on record for a higher number of violent crimes may have gained experience and skills beneficial for helping them to restrain themselves and therefore prevent a violent conflict from ending lethally (Ganpat et al., 2014). Indeed, it is possible that the Finnish scene of serious violence comparatively lacks such a sub- 
group, since it is known that gang and crime-related homicide is comparatively rare in Finland (Granath et al., 2011; Liem et al., 2013). In addition to this, the role of alcohol is an important feature of Finnish homicides, and the offenders and victims alike are older than in the Netherlands (Granath et al., 2011; Liem et al., 2013), and these characteristics may have an impact on the lethality as well.

As stated by Dobash et al. (2007), lethal violence occurs in the context of non-lethal violence. Based on our findings, we argue that it is not possible to predict whether a violent encounter will end lethally based on an offender's criminal history, or generally differentiate between offenders involved in more serious violence on the basis of background variables measured in this study. This suggests that interventions aimed at decreasing lethal violence should be targeted at a larger group of people: offenders of serious violent crime can all be seen as belonging to a risk group. As stated by prior research (Dobash et al., 2007; Ganpat et al., 2014; Soothill et al., 2002), not all homicide offenders had a prior criminal record. This emphasizes the need for future research to examine the context of violent encounters: the study of the immediate situational features of the violent event, as well as the social interaction and routine activities of the parties, would deepen our understanding of lethal violence.

\section{References}

Aaltonen, M. (2013). Socioeconomic Differences in Crime and Victimization. A Register Based Study. Doctoral dissertation. National Research Institute of Legal Policy research report 263, Helsinki. doi:10138/152463

Aaltonen, M. (2016). Post-release employment of desisting inmates. British Journal of Criminology, 56, 350-369. doi:10.1093/bjc/azv047 
Adams, J. J., \& Pizarro, J. M. (2014). Patterns of specialization and escalation in the criminal careers of gang and non-gang homicide offenders. Criminal Justice and Behavior, 41, 237-255. doi:10.1177/0093854813503637

Barnes, J.C., Beaver, K.M., \& Boutwell, B.B. (2011). Examining the genetic underpinnings to Moffitt's Developmental Taxonomy: A behavior genetic analysis. Criminology, 49, 923-954. doi: 10.1111/j.1745-9125.2011.00243.x

Bijleveld, C. C. J. H., \& Wijkman, M. D. S. (2009). Intergenerational continuity in convictions: a five-generation study. Criminal Behaviour and Mental Health, 19, 142155. doi: $10.1002 / \mathrm{cbm} .714$

Blumstein A., Cohen J., Das S., Moitra S. D. (1988). Specialization and seriousness during adult criminal careers. Journal of Quantitative Criminology, 4, 303-345. doi:10.1007/BF01065343

Byrd, A. L., \& Manuck, S. B. (2013). MAOA, childhood maltreatment, and antisocial behavior: meta-analysis of a gene-environment interaction. Biological Psychiatry, 75(1), 9-17. doi:10.1016/j.biopsych.2013.05.004

Caspi, A., Elder, G. H., \& Bem, D. J. (1987). Moving against the world: Life-course patterns of explosive children. Developmental Psychology, 23(2), 308-313. doi:10.1037/0012-1649.23.2.308

DeLisi, M., Kosloski, A., Sween, M., Hachmeister, E., Moore, M., \& Drury, A. (2010). Murder by numbers: Monetary costs imposed by a sample of homicide offenders. The Journal of Forensic Psychiatry \& Psychology, 21, 501-513.

DeLisi, M., Vaughn, M. G., Salas-Wright, C. P., \& Jennings, W. G. (2015). Drugged and dangerous prevalence and variants of substance use comorbidity among seriously violent offenders in the United States. Journal of Drug Issues, 45, 232-248. doi:10.1177/0022042615579237 
DiCataldo, F., \& Everett, M. (2008). Distinguishing Juvenile Homicide From Violent Juvenile Offending. International Journal of Offender Therapy and Comparative Criminology, 52, 158-174. doi:10.1177/0306624X07303906

Dobash, R. E., Dobash, R. P., Cavanagh, K., \& Medina-Ariza, J. (2007). Lethal and Nonlethal Violence Against an Intimate Female Partner. Violence Against Women, 13, 329-353. doi:10.1177/1077801207299204

Esping-Andersen, G. (1999). Social foundations of postindustrial economies. Oxford: Oxford University Press.

Farrington, D. P., Jolliffe, D., Loeber, R., Stouthamer-Loeber, M., \& Kalb, L.M. (2001). The concentration of offenders in families, and family criminality in the prediction of boys' delinquency. Journal of Adolescence, 24, 579-596. doi:10.1006/jado.2001.0424

Farrington, D. P., Loeber, R., \& Berg, M. T. (2012). Young Men Who Kill: A Prospective Longitudinal Examination From Childhood. Homicide Studies, 16, 99-128. doi:10.1177/1088767912439398

Felson, R. B., \& Lane, K. J. (2010). Does violence involving women and intimate partners have a special etiology? Criminology, 48, 321-338.

doi:10.1111/j.17459125.2010.00186.x

Ganpat, S. M., Liem, M. C. A., Van der Leun, J. P., \& Nieuwbeerta, P. (2014). The Influence of Criminal History on the Likelihood of Committing Lethal Versus Nonlethal Violence. Homicide Studies, 18, 221-240. doi:10.1177/1088767912466082

Gottfredson, M. R., \& Hirschi, T. (1990). A General Theory of Crime. Stanford: Stanford University Press.

Granath, S., Hagstedt, J., Kivivuori, J., Lehti, M., Ganpat, S.M, Liem, M.C.A, \& Nieuwbeerta, P. (2011). Homicide in Finland, the Netherlands and Sweden. A First Study on the European Homicide Monitor Data. Swedish National Council for Crime 
Prevention Research Report 2011:15; Oikeuspoliittisen tutkimuslaitoksen tutkimuksia 259. Stockholm: Brå. doi:10138/152494

Hardwick, P. J., \& Rowton-Lee, M. A. (1996). Adolescent homicide: towards assessment of risk. Journal of Adolescence, 19, 263-276. doi:10.1006/jado.1996.0024

Hsieh, C.-C., \& Pugh, M. D. (1993). Poverty, income inequality, and violent crime: a meta-analysis of recent aggregate data studies. Criminal Justice Review, 18, 182-202. doi:10.1177/073401689301800203

Kivivuori, J. (2007) Delinquent Behaviour in the Nordic Capital Cities. Scandinavian Research Council for Criminology \& National Research Institute of Legal Policy, Publication 227. Helsinki. doi:10138/152602

Kivivuori, J. (2011). Discovery of Hidden Crime. Self-Report Delinquency Surveys in Criminal Policy Context. Oxford: Oxford University Press.

Kivivuori, Janne (2017, forthcoming). Veli Verkko as an Early Criminologist: A Case Study in Scientific Conflict and Paradigm Shift. Scandinavian Journal of History.

Kivivuori, J., \& Lehti, M. (2006). The Social Composition of Homicide in Finland, 19602000. Acta Sociologica, 49, 67-82. doi:10.1177/0001699306061900

Kivivuori, J., \& Lehti, M. (2011). Homicide in Finland and Sweden. In M. Tonry \& T. Lappi-Seppälä (Eds.), Crime and Justice: A Review of Research, vol. 40 (pp. 109-198). Chicago: The University of Chicago Press.

Kivivuori, J., \& Lehti, M. (2012). Social Correlates of Intimate Partner Homicide in Finland: Distinct or Shared with Other Homicide Types? Homicide Studies, 16, 60-77. doi:10.1177/1088767911428815

Kääriäinen, J., Lehti, M., Danielsson, P., Aaltonen, M., Kuitunen, L., \& Salmi, V. (2016). Pahoinpitely- ja ryöstörikokset. Rikollisuustilanne 2015. Rikollisuuskehitys tilastojen ja tutkimusten valossa. Katsauksia 14/2016. Institute of Criminology and Legal Policy. 
University of Helsinki. doi:10138/164434

Lappi-Seppälä, T. (2011). Explaining imprisonment in Europe. European Journal of Criminology, 8, 303-328. doi:10.1177/1477370811411459

Le Blanc M, Loeber R. (1998). Developmental criminology updated. In: M. Tonry (ed.), Crime and Justice: A Review of Research, vol. 23 (pp. 115-198). Chicago: The University of Chicago Press.

Lehti, M., \& Kivivuori, J. (2005). Alcohol-related violence as an explanation for the difference between homicide rates in Finland and the other Nordic countries. Nordisk Alcohol- \& Narkotikatidskrift, 22, 7-24. English supplement.

Lehti, M., Suonpää, K., \& Kivivuori, J. (2016). Henkirikokset. Rikollisuustilanne 2015. Rikollisuuskehitys tilastojen ja tutkimusten valossa. Katsauksia 14/2016. Institute of Criminology and Legal Policy. University of Helsinki. doi:10138/164434

Liem, M. C. A., Ganpat, S., Granath, S., Hagstedt, J., Kivivuori, J., Lehti, M., \& Nieuwbeerta, P. (2013). Homicide in Finland, the Netherlands, and Sweden: First Findings From the European Homicide Monitor. Homicide Studies, 1, 75-95. doi:10.1177/1088767912452130

Lyngstad, T. H., \& Skardhamar, T. (2011). Nordic Register Data and Their Untapped Potential for Criminological Knowledge. In M. Tonry \& T. Lappi-Seppälä (Eds.), Crime and Justice: A Review of Research, vol. 40 (pp. 613-645). Chicago: The University of Chicago Press.

Martens, P. L., \& Holmberg, S. (2005). Brottslighet bland personer födda i Sverige och i utlandet [Crime among persons born in Sweden and abroad]. Stockholm: Brottsförebyggande rådet (BRÅ). 
McCuish, E. C., Corrado, R. R., Hart, S. D., \& DeLisi, M. (2015). The role of symptoms of psychopathy in persistent violence over the criminal career into full adulthood. Journal of Criminal Justice, 43, 345-356. doi:10.1016/j.jcrimjus.2015.04.008

Merton, R. K. (1938). Social structure and anomie. American Sociological Review, 3, $672-682$.

Merton, R. K. (1968). Social Theory and Social Structure. New York: The Free Press.

Messner, S. F. (1983). Regional Differences in the Economic Correlates of the Urban Homicide Rate. Criminology, 21, 477-488. doi:10.1111/j.1745-9125.1983.tb00275.x

Moffitt, T. E. (1993). Adolescence-Limited and Life-Course-Persistent Antisocial Behavior: A Developmental Taxonomy. Psychological Review, 100, 674-701. doi:10.1037/0033-295X.100.4.674

Moffitt, T. E. (2006). A Review of Research on the Taxonomy of Life-Course Persistent Versus Adolescence-Limited Antisocial Behavior. In F. T. Cullen, J. P. Wright, \& K. R. Blevins (Eds.), Taking stock: The status of criminological theory. Advances in criminological theory, vol. 15 (pp. 277-312). New Brunswick: Transaction.

Moffitt, T.E., Arseneault, L., Belsky, D., Dickson, N., Hancox, R. J., Harrington, HL.,..., Houts, R. (2011). A gradient of child-hood self-control predicts health, wealth and public safety. Proceedings of the National Academy of Sciences 108, 2693-98. doi:10.1073/pnas.1010076108

Piquero, A. R., Jennings, W. G., \& Barnes, J. C. (2012). Violence in criminal careers: A review of the literature from a developmental life-course perspective. Aggression and Violent Behavior, 17, 171-179. doi:10.1016/j.avb.2012.02.008

Piquero, A., MacDonald, J., Dobrin, A., Daigle, L., \& Cullen, F. (2005). Self-control, violent offending, and homicide victimization: Assessing the general theory of crime. Journal of Quantitative Criminology, 21, 55-71. doi:10.1007/s10940-004-1787-2 
Poijula, S. (2010). Henkirikosuhrien perheenjäsenten selviytyminen, mielenterveys ja kokemukset tuesta ja palveluista. Sosiaali- ja terveysministeriön selvityksiä 2010:10, Helsinki.

Rhee, S. H., \& Waldman, I. D. (2002). Genetic and environmental influences on antisocial behavior: A meta-analysis of twin and adoption studies. Psychological Bulletin, 128, 490-529. doi:10.1037//0033-2909.128.3.490

Saarikkomäki, E., \& Kivivuori, J. (2013). Young People as Objects of Police Control in a Nordic Context: Who Are the Socially Visible Targets? European Journal on Criminal Policy and Research, 19, 351-368. doi:10.1007/s10610-013-9204-8

Sampson, R. J., \& Laub, J. H. (1997). A Life-Course Theory of Cumulative Disadvantage and the Stability of Delinquency. In T. P. Thornberry (Ed.), Developmental Theories of Crime and Delinquency. New Brunswick, N.J.: Transaction Publishers.

Savolainen, J., Lehti, M., \& Kivivuori, J. (2008). Historical Origins of a Cross-National Puzzle. Homicide in Finland, 1750 to 2000. Homicide Studies, 12, 67-89. doi:10.1177/1088767907311850

Skardhamar, T., Aaltonen, M., \& Lehti, M. (2014). Immigrant crime in Norway and Finland. Journal of Scandinavian Studies in Criminolog and Crime Prevention, 15, 107-127. doi:10.1080/14043858.2014.926062

Slutske, W. (2001). The Genetics of Antisocial Behavior. Current Psychiatry Reports, 3, 158-162. doi:10.1007/s11920-001-0014-1

Smit, P., Bijleveld, C. C. J. H., Brouwers, M., Loeber, R., \& Nieuwbeerta, P. (2003). Differences between convicted violent offenders: Completed and attempted homicides and aggravated assaults. In C. R. Block \& R. R. Block (Eds.), Public health and criminal justice approaches to homicide research. Proceedings of the 2003 meeting of the Homicide Research Working Group (pp. 281-286). Chicago, IL: Homicide 
Research Working Group.

Soothill, K., Francis, B., Ackerley, E., \& Fligelstone, R. (2002). Murder and serious sexual assault: What criminal histories can reveal about future serious offending. Police Research Series, Paper 144. London: Home Office.

Van Dijk, J., Van Kesteren, J., \& Smit, P. (2007). Criminal Victimisation in International Perspective. Key findings from the 2004-2005 ICVS and EU ICS. Retrieved from: http://www.unicri.it/services/library_documentation/publications/icvs/publications/ICV S2004_05report.pdf.

Weijer, S. G. A. van de, Bijleveld, C. C., \& Blokland, A. A. (2014). The Intergenerational Transmission of Violent Offending. Journal of Family Violence, 29, 109-118. doi:10.1007/s10896-013-9565-2

WHO. (2013). The raw data files of the WHO Mortality Database. Retrieved May 8, 2014, from World Health Organization.

Wickramasekera, N., Wright, J., Elsey, H., Murray, J., \& Tubeuf, S. (2015). Cost of crime: A systematic review. Journal of Criminal Justice, 43(3), 218-228.

Zimring, F. E., \& Hawkins, G. (1999). Crime Is Not the Problem: Lethal Violence in America. New York: Oxford University Press. 


\section{Tables and Figures}

Table 1: Descriptive results of different types of violent offenders $(\mathrm{N}=26,303)$.

N

Demographic information

Male (\%)

Mean age at index offence

Standard deviation of the age

Immigrant background (\%)

Individual criminal propensity

Violent sentence (\%)

Drug-related sentence (\%)

Property crime sentence (\%)

Prior incarceration (\%)

Parental criminal propensity

At least one parent had prison sentence $(\mathrm{N}=22,391)$

Social disadvantage and strain

Mean annual income $(€)$

Standard deviation of the income

Lack of secondary education (\%)

\begin{tabular}{ccccc}
$\begin{array}{c}\text { Minor } \\
\text { assault }\end{array}$ & Assault & $\begin{array}{c}\text { Aggravated } \\
\text { assault }\end{array}$ & $\begin{array}{c}\text { Attempted } \\
\text { homicide }\end{array}$ & $\begin{array}{c}\text { Completed } \\
\text { homicide }\end{array}$ \\
\hline 7,970 & 15,817 & 1,995 & 318 & 203 \\
79.0 & 84.3 & 83.7 & 83.6 & 88.7 \\
34 & 33 & 33 & 36 & 37 \\
13.6 & 12.7 & 12.2 & 12.4 & 13.0 \\
12.4 & 13.0 & 11.2 & 8.8 & 7.9 \\
& & & & \\
11.5 & 14.6 & 29.3 & 31.4 & 35.0 \\
6.0 & 8.4 & 18.5 & 24.2 & 18.7 \\
21.5 & 25.7 & 42.3 & 48.7 & 44.3 \\
6.6 & 8.4 & 21.5 & 28.3 & 27.1 \\
& & & & \\
8.2 & 9.3 & 12.9 & 11.3 & 13.1 \\
12,807 & 11,244 & 7,482 & 6,654 & 7,219 \\
14,736 & 13,522 & 9,254 & 7,642 & 8,465 \\
52.1 & 56.4 & 66.5 & 68.2 & 58.6
\end{tabular}


Figure 1: Associations (odds ratios) between the severity of violent offending (reference group: Assault) and prior criminal history $(\mathrm{N}=26,303)$, logistic regression.

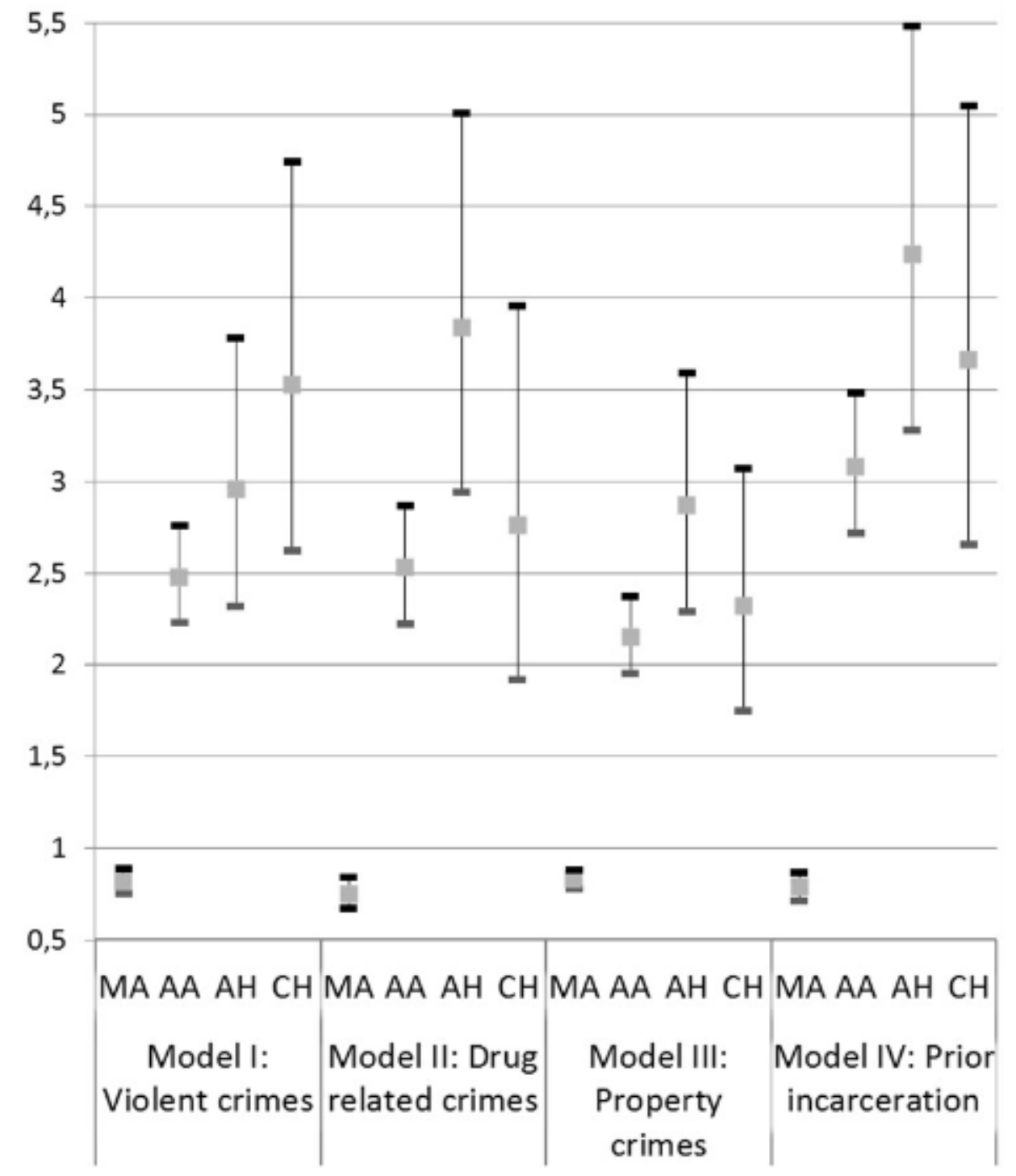

$\mathrm{MA}=$ Minor assault, $\mathrm{AA}=$ Aggravated assault, $\mathrm{AH}=$ Attempted homicide, $\mathrm{CH}=$ Completed homicide 
Figure 2: Association (odds ratio) between the severity of violent offending (reference group: Assault) and parental incarceration $(\mathrm{N}=22,391)$, logistic regression.

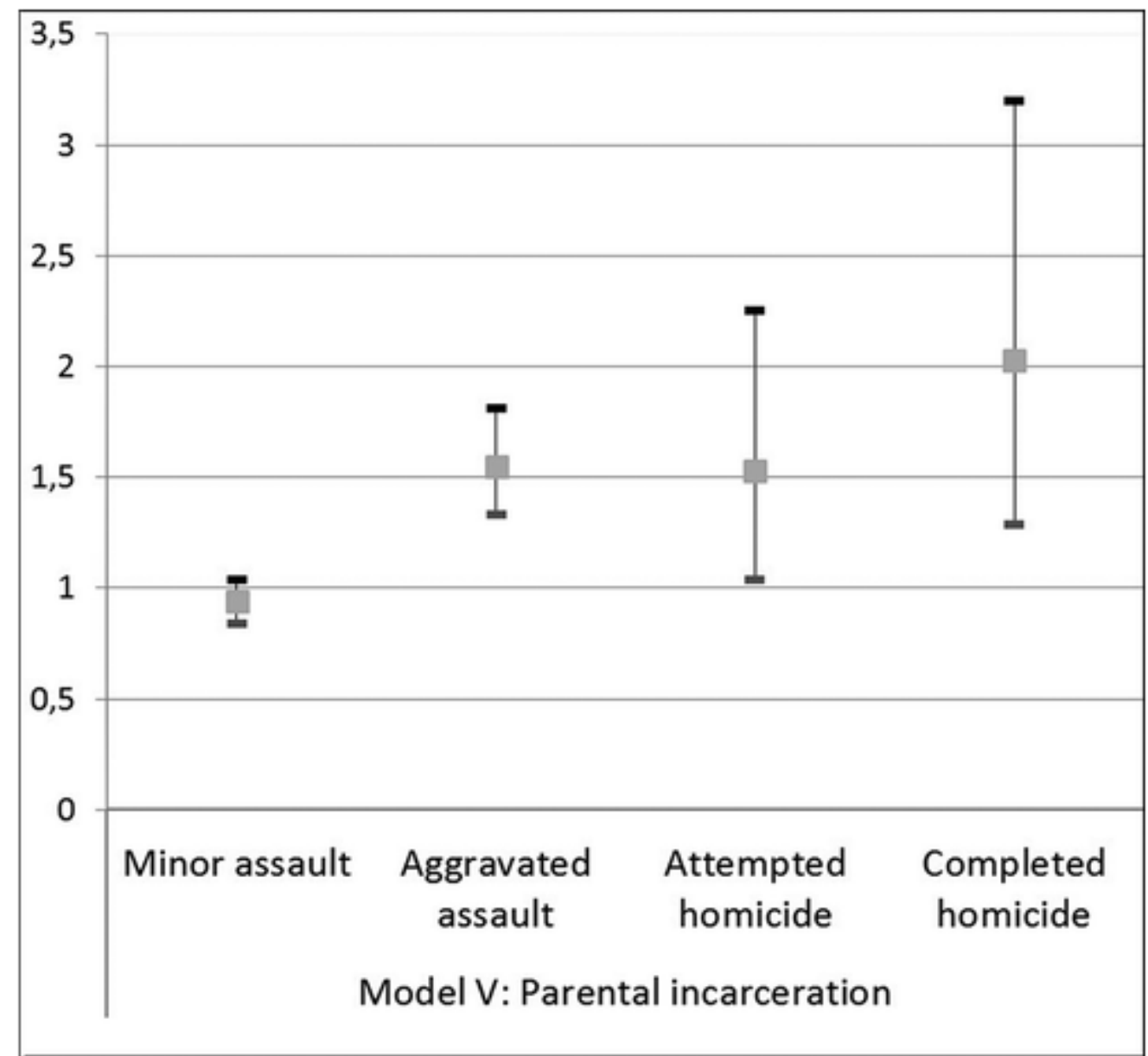

$\mathrm{MA}=$ Minor assault, $\mathrm{AA}=$ Aggravated assault, $\mathrm{AH}=$ Attempted homicide, $\mathrm{CH}=\mathrm{Completed}$ homicide 
Figure 3: Association between the severity of violent offending (reference group: Assault) and annual income $(€)$ during the last 5 years before the index crime $(\mathrm{N}=26,303)$, linear regression.

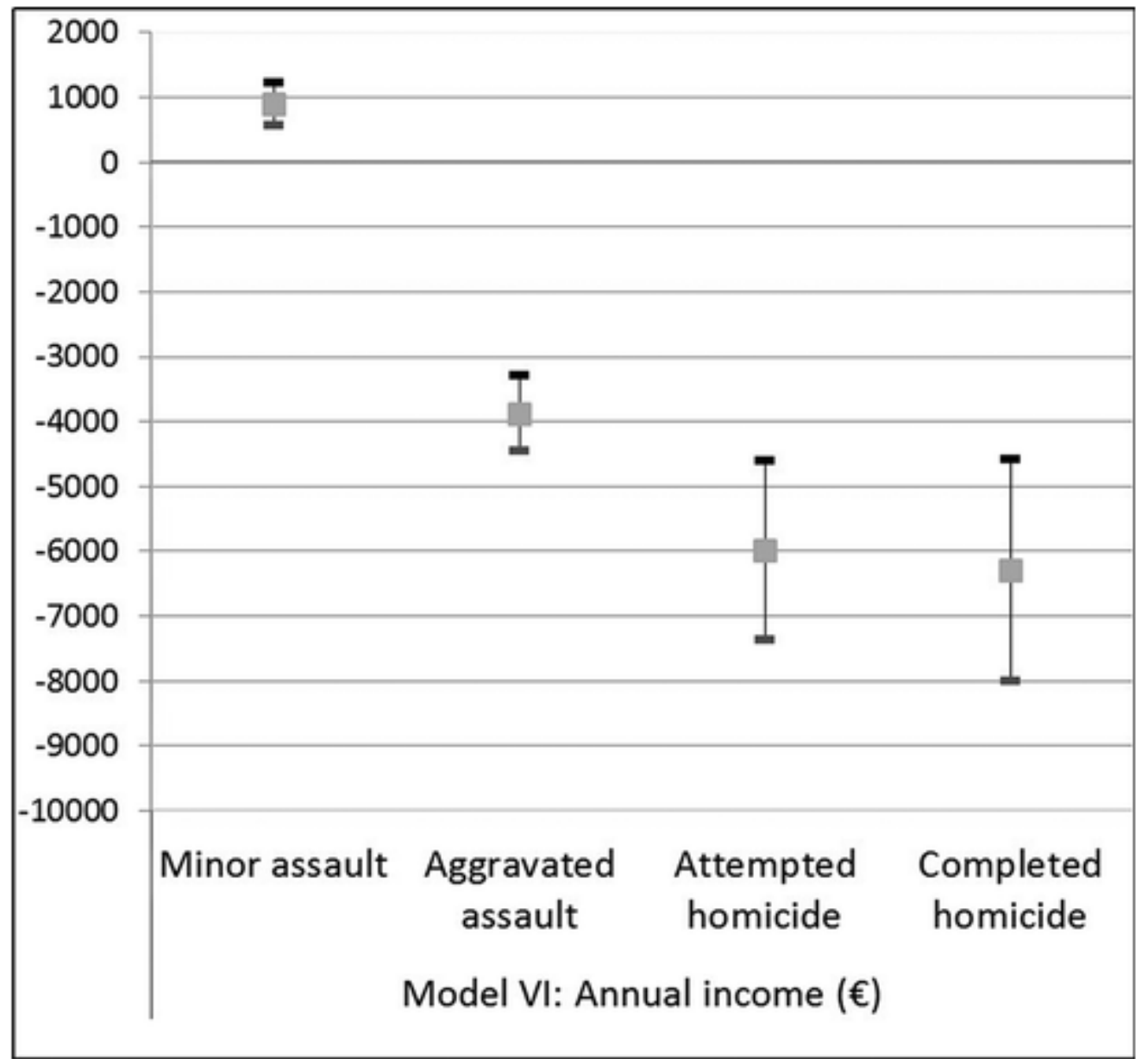

$\mathrm{MA}=$ Minor assault, $\mathrm{AA}=$ Aggravated assault, $\mathrm{AH}=$ Attempted homicide, $\mathrm{CH}=$ Completed homicide 
Figure 4: Associations (odds ratios) between the severity of violent offending (reference group: Assault) and measures of strain and social disadvantage $(\mathrm{N}=26,303)$, logistic regression.

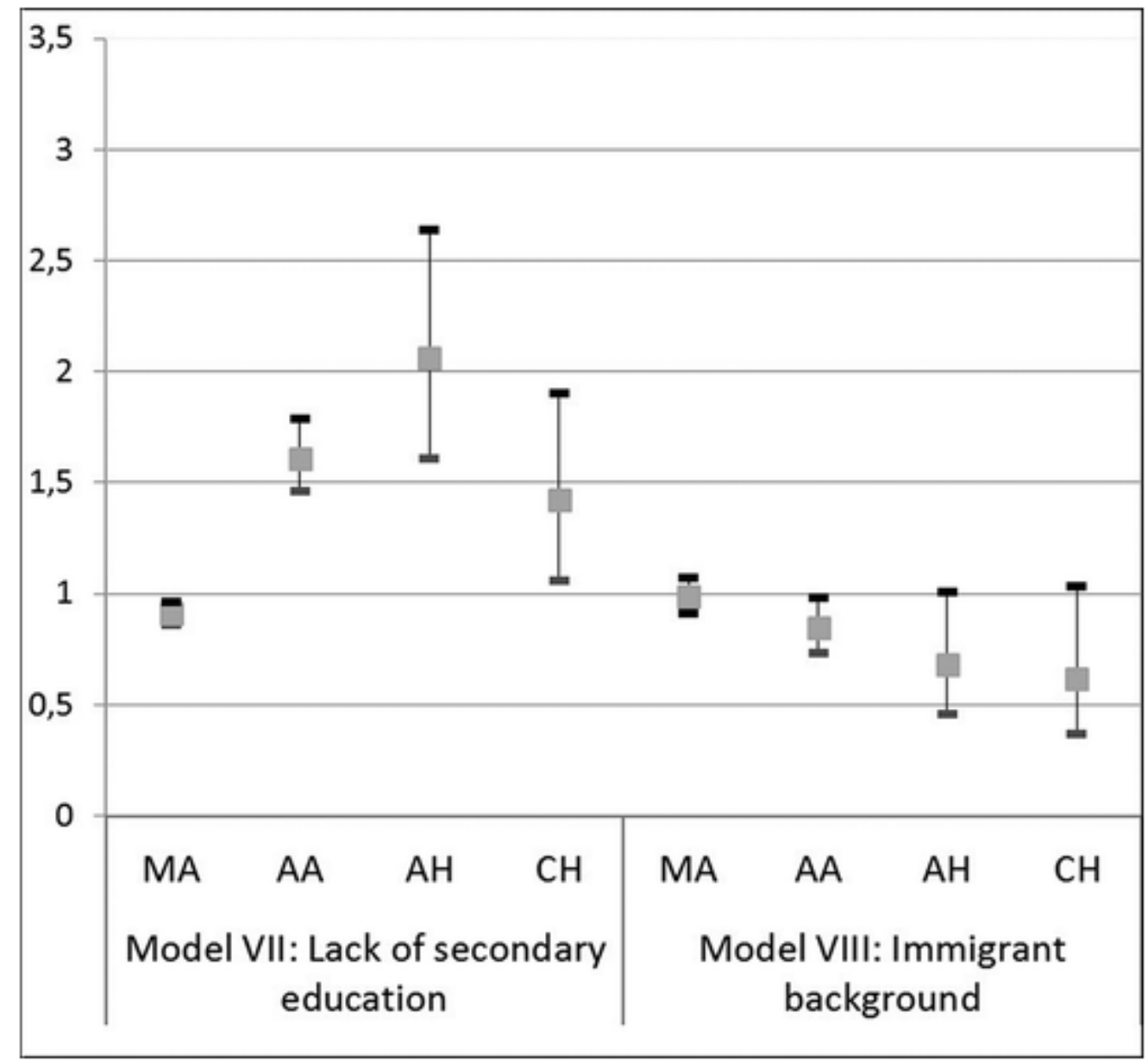

$\mathrm{MA}=$ Minor assault, $\mathrm{AA}=$ Aggravated assault, $\mathrm{AH}=$ Attempted homicide, $\mathrm{CH}=\mathrm{Completed}$ homicide 
Appendix

Table 2: Association (odds ratios) of the severity of violent offending (reference group: assault) and prior criminal history $(\mathrm{N}=\mathbf{2 6 , 3 0 3 )}$, logistic regression.

\begin{tabular}{|c|c|c|c|c|c|c|c|c|c|c|c|c|}
\hline \multirow{3}{*}{ Variable } & \multicolumn{3}{|c|}{$\begin{array}{l}\text { Model I } \\
\text { Violent sentence }\end{array}$} & \multicolumn{3}{|c|}{$\begin{array}{l}\text { Model II } \\
\text { Drug-related sentence }\end{array}$} & \multicolumn{3}{|c|}{$\begin{array}{l}\text { Model III } \\
\text { Property crime sentence }\end{array}$} & \multicolumn{3}{|c|}{$\begin{array}{l}\text { Model IV } \\
\text { Prior incarceration }\end{array}$} \\
\hline & $\operatorname{Exp}(B)$ & 95\% C.I. & & $\operatorname{Exp}(B)$ & 95\% C.I. & & $\operatorname{Exp}(B)$ & 95\% C.I. & & $\operatorname{Exp}(B)$ & $95 \%$ C.I. & \\
\hline & & Lower & Upper & & Lower & Upper & & Lower & Upper & & Lower & Upper \\
\hline Minor assault & 0.818 & 0.753 & 0.889 & 0.751 & 0.673 & 0.837 & 0.829 & 0.776 & 0.884 & 0.785 & 0.706 & 0.872 \\
\hline Aggravated assault & 2.478 & 2.225 & 2.759 & 2.526 & 2.224 & 2.870 & 2.150 & 1.952 & 2.369 & 3.076 & 2.721 & 3.477 \\
\hline Attempted homicide & 2.958 & 2.316 & 3.777 & 3.840 & 2.941 & 5.014 & 2.865 & 2.285 & 3.592 & 4.240 & 3.282 & 5.479 \\
\hline Completed homicide & 3.525 & 2.621 & 4.741 & 2.756 & 1.920 & 3.955 & 2.315 & 1.746 & 3.069 & 3.664 & 2.660 & 5.048 \\
\hline
\end{tabular}

Model I-IV: Gender, age, and immigrant status are controlled for. 
Table 3: Associations (odds ratios) of the severity of violent offending (reference group: assault) and parental incarceration $(\mathrm{N}=\mathbf{2 6 , 3 0 3 )}$, logistic regression.

\begin{tabular}{lrrr} 
Model V: Parental incarceration \\
& Exp(B) & $95 \%$ C.I. \\
& & Lower & Upper \\
Minor assault & 0.936 & 0.841 & 1.042 \\
Aggravated assault & 1.551 & 1.327 & 1.814 \\
Attempted homicide & 1.526 & 1.037 & 2.245 \\
Completed homicide & 2.033 & 1.291 & 3.200 \\
\hline
\end{tabular}

Gender, age, and immigrant status are controlled for.

Table 4: Associations of the severity of violent offending (reference group: assault) and measures of strain and social disadvantage $(\mathrm{N}=\mathbf{2 6 , 3 0 3})$.

Model VI: Annual income

B

95\% C.I.

Lower Upper

Minor assault $\quad 904.888 \quad 571.076 \quad 1238.7$

Aggravated assault $\quad$ 3867.96i.4442.84:3293.089

Attempted homicide $\quad .5977 .9717348 .83 \$ 4607.105$

Completed homicide $\quad 6279.37$ c.7989.23\$.4569.521

Gender, age, and immigrant status are controlled for. 
Table 5: Associations (odds ratios) of the severity of violent offending (reference group: assault) and measures of strain and social disadvantage $(\mathrm{N}=26,303)$, logistic regression.

\begin{tabular}{|c|c|c|c|c|c|c|}
\hline & \multicolumn{3}{|c|}{ Model VII } & \multicolumn{3}{|c|}{ Model VIII } \\
\hline & \multicolumn{6}{|c|}{ Lack of secondary educati Immigrant background } \\
\hline & \multirow[t]{2}{*}{$\operatorname{Exp}(B)$} & \multicolumn{2}{|c|}{ 95\% C.I. } & \multirow[t]{2}{*}{$\operatorname{Exp}(B)$} & \multicolumn{2}{|c|}{ 95\% C.I. } \\
\hline & & Lower & Upper & & Lower & Upper \\
\hline Minor assault & 0.909 & 0.859 & 0.963 & 0.985 & 0.908 & 1.069 \\
\hline Aggravated assault & 1.614 & 1.457 & 1.788 & 0.847 & 0.731 & 0.981 \\
\hline Attempted homicide & 2.063 & 1.610 & 2.642 & 0.682 & 0.461 & 1.009 \\
\hline Completed homicide & 1.418 & 1.056 & 1.903 & 0.616 & 0.369 & 1.030 \\
\hline
\end{tabular}

Model VI-VII: Gender, age, and immigrant status are controlled for.

Model VIII: Gender and age are controlled for. 